\title{
Instrument for evaluating digital educational comic
}

\author{
Syamsul Bahrin Zaibon ${ }^{1 *}$, Farah Nadia Azman ${ }^{2}$ and Norshuhada Shiratuddin ${ }^{3}$ \\ Associate Professor, School of Creative Industry Management \& Performing Arts, Universiti Utara Malaysia, \\ Malaysia $^{1}$ \\ Senior Lecturer, Universiti Teknikal Malaysia Melaka, Durian Tunggal, Malaysia ${ }^{2}$ \\ Professor, Universiti Utara Malaysia, Sintok, Kedah, Malaysia ${ }^{3}$
}

Received: 1-October-2018; Revised: 7-January-2019; Accepted: 30-January-2019

(C)2019 Syamsul Bahrin Zaibon et al. This is an open access article distributed under the Creative Commons Attribution (CC BY) License, which permits unrestricted use, distribution, and reproduction in any medium, provided the original work is properly cited.

\begin{abstract}
Digital educational comic allows learners' knowledge and ideas on various subjects to be synthesized in a form of digital comic. Digital educational comic not only contains informative and emotive elements, but also engages the learners emotionally. In order to know the digital educational comic is valuable to leaners, it is needed to be evaluated properly. In specific, it should be measured based on what level it is able to educate and entertain the leaners. However, to date the standard evaluation of digital educational comic is scarce. Therefore, this paper aims to present the design, development, and validation of an instrument for evaluating digital educational comic. The instrument focuses on evaluating two main aspects of the digital educational comic: learning (12 items) and entertainment ( 8 items) which were based on the literature of comic core elements. Content validity, face validity, and reliability tests were carried out and the instrument shows satisfactory properties and could be useful in the educational environment and research. The use of the instrument may contribute to a deeper understanding of digital educational comic properties, valuable for comic development and improvements of quality in comic educational content.
\end{abstract}

\section{Keywords}

Digital educational comic, Instrument development, Evaluation of comic, Learning and entertainment content.

\section{Introduction}

Unlike regular books, paintings, or movies, comics are collectively no better nor worse than other media, but simply different [1]. Hence, the terminology of "comic" itself is a widely debated point in comic scholarship. For example, in the book of critical essays on comics by Varnum and Gibbons [2], the definition of comics is compiled as "a narrative form consisting of pictures arranged in sequence," (p. xvi). Beforehand, comic book creator Eisner [3] (1985) specified comic as "sequential art" or "the arrangement of pictures or images and words to narrate a story or dramatize an idea," (p. 5). McCloud [4] later revised the term of comic as "juxtaposed pictorial and other images in a deliberate sequence, invented to convey information and/or to produce an aesthetic response in the viewer," (p. 5). In contrast, Cohn [5] was critical towards a definition of comic as a language. As a substitute, he stated that comics are social artefacts that communicated in visual language.

*Author for correspondence

316
Despite the contradictions between the authors, there is a significant consistency in their writings where comic appears to retain several key features: narratives, pictures, images or arts; and sequences. Using these mutual characteristics, Tatalovic [6] categorized comics into single-frame cartoons, short comic strips, comic books, and graphic novels in terms of length and narrative complexity level. Additionally, it is important to clarify that picture books are not comics because their definition finds no adherence to the non-structural conception of comics [7] despite sharing substantial common ground [8].

With the arrival of digital technology and displays, the medium of comics is undergoing a transition, such as pacing of digital comic sequences is affected by replacements of page turn, panel spacing and layout influenced by canvas scrolls [9]. The advancement in the digital comic could be realized in the interaction styles. These interaction styles of digital comic involve eye-tracking, voice control, facial expression recognition, gesture recognition, 
key-board control, touch screen control, and handle control [10]. Spectacular reading experience is also offered in digital comics that incorporate rich multimedia elements of audio to animation [11], as well as accepting mouse click, drag, text, and touch input $[12,13]$. Despite the technological progression, animated illustrations, music, and sound effects were found to be beneficial in multimedia stories while interactive elements such as hotspots and games are distracting in contrast [14].

As a further remark, hypercomics expands the feature of digital comic with non-linear story structure [15]. One of the various types of digital narratives are stories that meant to inform and instruct [16]. Instructional messages are integrated with learning activities to create more engaging and exciting learning environments [17] by allowing learners to self-reflect on their thinking in their digital story [18]. Similar to educational comic, it signifies a unique nexus of numerous visual storytelling techniques [19]. According to Jüngst [20], educational comic narrative may contain informative and emotive elements. Essentially, the value of digital educational comics not only relies on how successful they are in delivering instructive content, but also engages the audiences emotionally. While some learners saw significance in the technical aspects of educational comics, others enjoyed being both educated and entertained [21].

\subsection{The need of digital educational comic} evaluation

In comic development, from idea generation until through completed comic, evaluation needs to be incorporated into the development process. Evaluation is needed to provide the educators and developers with more direction about what constitutes effective and high-quality educational comic. As stated by Guimarães [22], the comics that are used for the representation of scientific information must "be as accurate as the researchers who are producing Science. In other words, they should incorporate all the features of scientific behavior, such as objectivity, factualness, impartiality etc.". A problem facing many educators is how to evaluate comic for instructional content. This was apparent when many researchers found comic is one of the powerful tools that provide learning and entertainment at the same time. Recent years have witnessed a growing appreciation towards educational comics which are now capable to address almost any subject from fiction to non-fiction, without age boundaries [23] and relevance of comic in classroom [24].

Therefore, the aim of this paper is to discuss the design, development, and validation of the instrument for evaluating digital educational comic; which focus on the learning (in-formative) and entertainment (emotive) aspects of the digital educational comics.

\section{Methodology}

Learner-generated comic instrument consists of structured questionnaire is constructed according to [25] instrument design method as shown in Figure 1. The instrument design does not employ reverseworded statements based on the evidences that negatively-worded items do not prevent acquiescence response bias [26, 27].

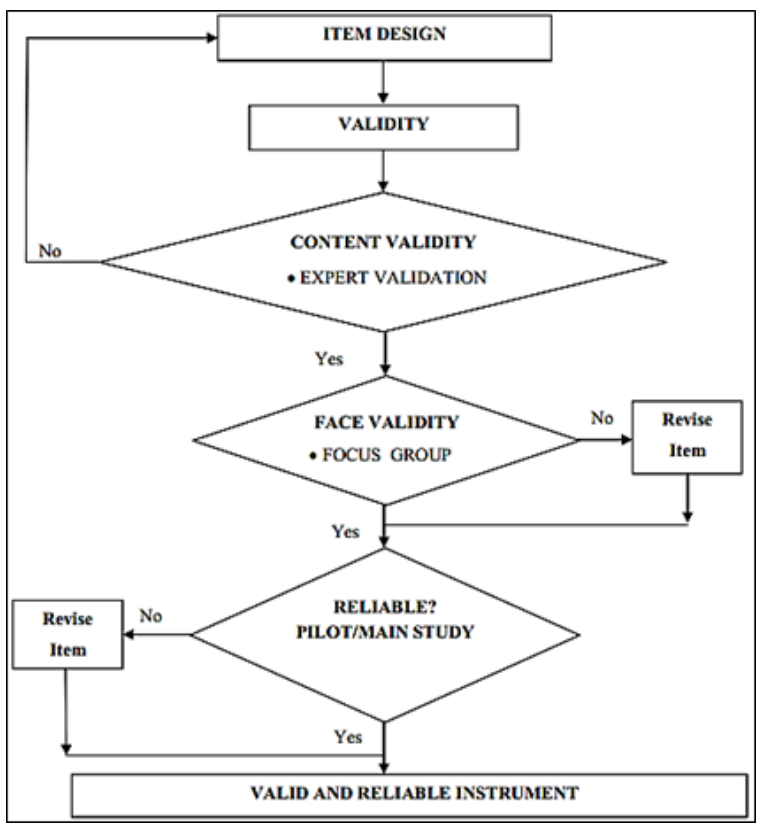

Figure 1 Questionnaire instrument design method [25]

\subsection{Item design}

Based on the previous discussion of the digital educational comic characteristics, it should be measured based on what level it is able to educate and entertain the readers. Compiling the comic characteristics found in articles and books by various authors: an analysis was developed (Table 1). The digital educational comic evaluation instrument contains two major dimensions; namely learning and entertainment. Principally, naming the aspects within dimension is based on learning content quality criteria associated with content and format by [26] 
and [27]'s coding scheme for learning objects assessment.

These item statements give attention on the comic core elements. Hence, an ordinal scale review form by Cooper [28] is adapted as it contains standards for the particular educational topic or subject and comic literary. Griffith [29]'s assessment criteria for school library graphic novel is also adapted into the questionnaire. Besides that, educational comic attributes in Cirigliano [21]'s experiment are also replicated in the instrument design. The analysis on evaluation criteria is exhibited in Table 1.

Table 1 Analysis on evaluation criteria for digital educational comic

\begin{tabular}{|c|c|c|c|}
\hline \multicolumn{2}{|c|}{ Aspects } & \multirow[t]{2}{*}{ Description } & \multirow[t]{2}{*}{ Source } \\
\hline (1) $\mathrm{Le}$ & ning: Intention & & \\
\hline L1 & $\begin{array}{l}\text { Learning Goal } \\
\text { Alignment }\end{array}$ & $\begin{array}{l}\text { At what level the comic's ideas/questions/facts/pieces of information are } \\
\text { relevant to the topic? }\end{array}$ & $\begin{array}{l}{[26,28 \text {, and }} \\
29]\end{array}$ \\
\hline L2 & Agility & $\begin{array}{l}\text { To what degree the text element in the comic is presented in short, concise } \\
\text { segments? }\end{array}$ & [26] \\
\hline L3 & Typography & $\begin{array}{l}\text { To what extent the font shapes, colours and size facilitate and stimulate } \\
\text { reading? }\end{array}$ & [26 and 29] \\
\hline L4 & Consistency & $\begin{array}{l}\text { To what degree the comic makes use of certain pictorial consistency which } \\
\text { adds significantly to the learning process? }\end{array}$ & [26] \\
\hline L5 & Recipient & $\begin{array}{l}\text { To what degree does the comic promote a positive attitude toward the topic? } \\
\text { To what degree does the comic respect the reader by presenting positive } \\
\text { race/gender/ethical, and/or cultural values? } \\
\text { To what extent do the comic's readability and interest level developmentally } \\
\text { appropriate for universal audience? }\end{array}$ & [26 and 29] \\
\hline L6 & Reusability & $\begin{array}{l}\text { To what degree do the digital comic's native files work efficiently for } \\
\text { different users in different digital environments and in different educational } \\
\text { contexts over time? } \\
\text { At what level the native file self-contained, modular, traceable, modifiable, } \\
\text { usable, standardized and properly grained, generic, and platform } \\
\text { independent? }\end{array}$ & [30] \\
\hline \multicolumn{4}{|c|}{ (2) Learning: Outcome } \\
\hline L7 & Accuracy & $\begin{array}{l}\text { At what level the ideas/questions/facts/pieces of information in the comic is } \\
\text { accurate, free of errors, and fact-checked? }\end{array}$ & [26 and 28] \\
\hline L8 & Reliability/ References & At what level the quoted materials are visibly cited? & [26] \\
\hline L9 & $\begin{array}{l}\text { Argumentation/ } \\
\text { Constructive Activity }\end{array}$ & $\begin{array}{l}\text { At what level the ideas/questions/facts in the story are sufficient in number } \\
\text { and scope to support the targeted educational outcomes? } \\
\text { To what extent do the comic generate ideas/questions/facts/pieces of } \\
\text { information about the topic? }\end{array}$ & $\begin{array}{l}{[21,27 \text { and }} \\
29]\end{array}$ \\
\hline L10 & Thoroughness & $\begin{array}{l}\text { At what level the characters/personas interaction with the educational } \\
\text { content are meaningful and permit the reader to have a much greater } \\
\text { understanding of the concept/topic? }\end{array}$ & $\begin{array}{l}{[21,26 \text { and }} \\
29]\end{array}$ \\
\hline L11 & $\begin{array}{l}\text { Emphasis of Key } \\
\text { Concepts }\end{array}$ & $\begin{array}{l}\text { To what extent the comic's pictorials facilitate the reader's involvement in, } \\
\text { understanding of, and use/transfer of its educational content? } \\
\text { At what level the ideas/questions/facts/pieces of information in the comic } \\
\text { are easily balanced, distinguished or discernible from fiction or fantasy? }\end{array}$ & [27 and 28] \\
\hline L12 & Prospective & $\begin{array}{l}\text { To what degree the story potentially open for sequel or continuation? } \\
\text { To what extent the comic ending trigger further questions related to the } \\
\text { educational topic? }\end{array}$ & [26 and 29] \\
\hline \multicolumn{4}{|c|}{ (3) Entertainment: Aesthetics } \\
\hline E1 & Visual Appeal & $\begin{array}{l}\text { At what level the comic's illustrations/photos/graphics are appealing? } \\
\text { To what degree the colour palette (e.g., pastels, primary colours, sepia } \\
\text { tones) aid the reader in understanding the tone and mood of the story? } \\
\text { To what extent the comic contains a vivid and interesting writing style that } \\
\text { actively involves the reader? }\end{array}$ & $\begin{array}{l}{[21,27 \text { and }} \\
29]\end{array}$ \\
\hline & Layout & $\begin{array}{l}\text { To what extent do the pictorials and words complement one another? } \\
\text { At what level the contrast and effects are used effectively to aid focus? }\end{array}$ & [27 and 28] \\
\hline
\end{tabular}




\begin{tabular}{clll}
\hline \multicolumn{1}{c}{ Aspects } & \multicolumn{1}{c}{ Description } \\
\hline E3 & Clear Instructions & $\begin{array}{l}\text { Tource what extent the story pace, shot, direction natural \& make sense to the } \\
\text { reader? } \\
\text { To what degree the characters position are reasonably placed? }\end{array}$ \\
\hline E4 & Navigation & $\begin{array}{l}\text { To what degree the comic panels, speech balloons and captions placement } \\
\text { ease and flow of the story? } \\
\text { At what level the white space between the text, frames, and illustrations help } \\
\text { readers move through the comic, or are the pages too busy? }\end{array}$ \\
\hline (4) Entertainment: Enjoyment & [27 and 29] \\
\hline E5 & Organization & $\begin{array}{l}\text { To what degree does the comic have a beginning, middle, and end? } \\
\text { To what degree does the comic have a well-described setting? }\end{array}$ \\
\hline E6 & Plot & $\begin{array}{l}\text { To what extent the plot exhibit good development, imagination, and } \\
\text { continuity? } \\
\text { To what extent does the resolution bring the conflict to a satisfying end? }\end{array}$ \\
\hline E7 & Characters & $\begin{array}{l}\text { To what extent the characters are believable and well developed? } \\
\text { To what degree the characters' pose, gesture \& expression make sense in the } \\
\text { story? }\end{array}$ \\
\hline E8 & Feedback & $\begin{array}{l}\text { At what level the comic provides enough context and action to keep the } \\
\text { reader moving through the story? } \\
\text { At what level the plot necessarily gives user adequate direction and } \\
\text { information for progressing to? }\end{array}$ \\
\hline
\end{tabular}

\section{Content and face validity}

Content validity refers to the ability of the instrument adequate and represent the overall aspects of digital educational comics while face validity is tested in order to know whether the instrument apparently linguistically and analytically look like what is supposed to be measured [31]. To perform both content and face validity of the instrument items, five experts comprising academicians in digital educational media design and development are officially appointed to review the instruments. Based on their knowledge, expertise, skills, and experiences in the above-mentioned field, they are required to rate the relevance of each item in the questionnaire: Essential, Useful but not essential, or Not necessary. Figure 2 shows example of content and face validity form which was provided to the experts.

The experts also indicate whether the items and keywords meet the appropriate standards of media production, accurately reflect the dimension category, capture the entire scope of the digital storytelling domain, and other required details or additional suggestion to improve the instrument [32]. Their critiques were reflected where several associated items are rephrased and improved.

Contiguously, face validity was also performed involving a focus group of ten students as the potential users in understanding the questionnaire. The questionnaire items are modified according to their feedback and agreement during the discussion. The criteria of face validity assessment of this study are based on [33] namely:

- Appropriateness of grammar

- The clarity and unambiguity of items

- The correct spelling of words

- The correct structuring the sentences

- Appropriateness of font size

- Consistency of style and formatting 


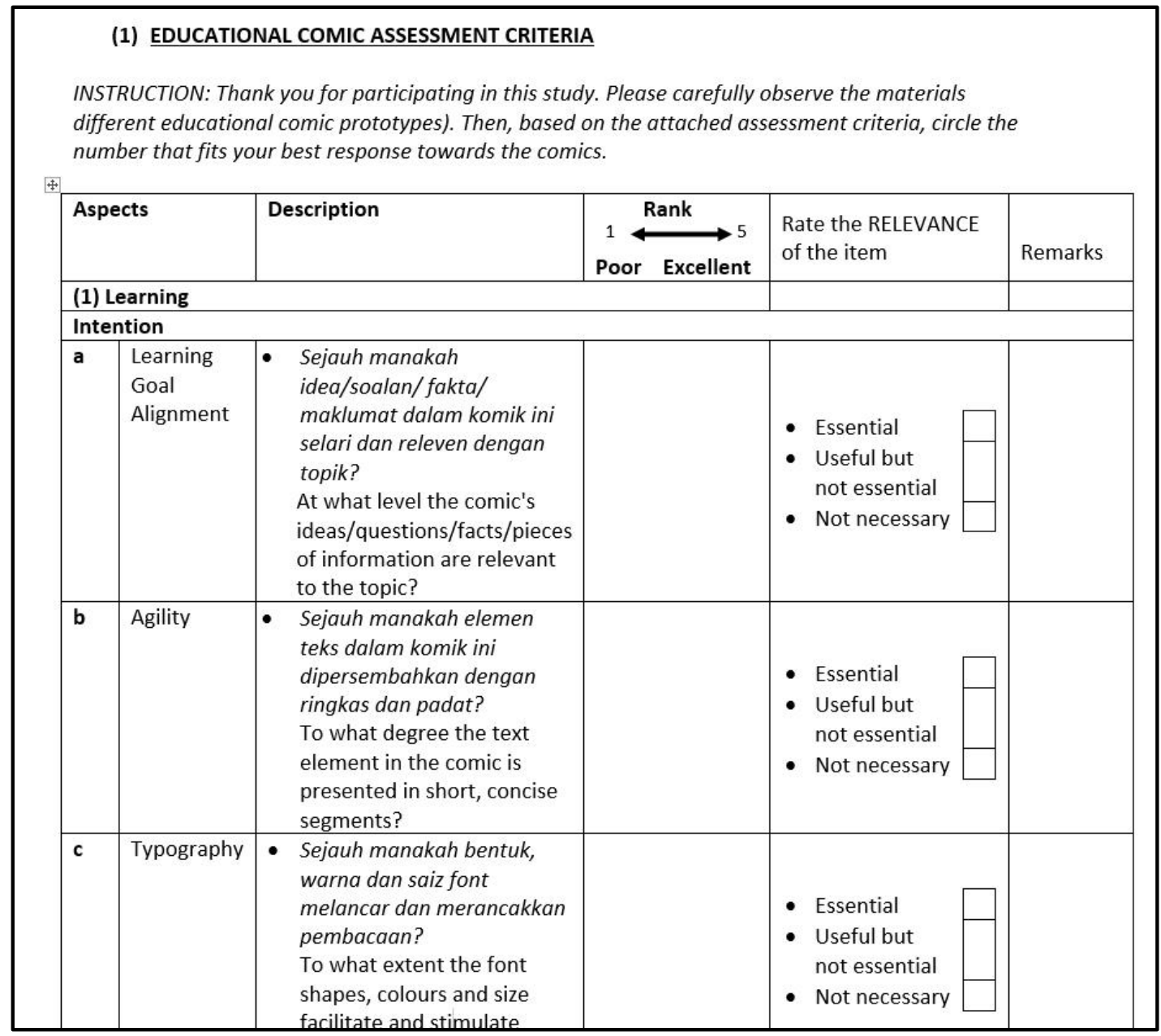

Figure 2 Example of content and face valid form

\section{Pilot study}

In order to test the reliability, consistency, and stability of the instrument, a pilot study involving 98 undergraduate students of a single university was conducted. The 98 respondents completed the questionnaire, and this number is adequate to obtain reliable results in response to [34, 35] who suggest employing at least 30 datasets for obtaining reliable results in statistical tests. During the data collection, the researcher detects and records any content of the questionnaire that failed to be recognized or understand by the respondents.

After the pilot study, statistical test was conducted where factor analysis and Cronbach alpha test are executed to measure the reliability of the instrument. Firstly, the value of Kaiser-Meyer-Olkin (KMO) and Bartlett 's test of sphericity is calculated. The results are depicted in Table 2. According to [36] the condition of factor analysis is KMO value must be greater than 0.50 while Bartlett 's test must have significant value of $\mathrm{p}$ less than 0.0 . It is required that the instrument must be greater than 0.5 factor loading rule [37]. Therefore, results from Table 2 demonstrate that the stated conditions are significantly fulfilled.

Next, the factor loading value conditions were also accomplished where all 20 items obtained greater than 0.5 scores (see Table 3). Four principle components were also successfully extracted that explained $66.289 \%$ of the total variance.

Finally, Cronbach 's Alpha test was run to remove items which do not concur to the minimum value of 0.7 [38] or above 0.6 [31]. Plus, to test instrument consistency, value of Cronbach's alpha coefficient indicates that $\alpha>0.7$ to be accepted as reliable [38]. Accordingly, Cronbach 's Alpha test for learner- 
generated comic instrument discloses significant results as presented in Table 4.

These findings exhibited that the instrument design is consistent. From the content validity, face validity, and reliability tests which were carried out, the instrument shows satisfactory properties and could be useful in developing and evaluating digital educational comic. The use of the instrument may contribute to a deeper understanding of digital educational comic properties, valuable for comic development and evaluation, and improvements of quality in comic educational content. Thus, the finalized instrument is presented in Table 5. It was apparent that Table 5 shows the final version of the instrument for evaluating digital educational comic, which caters for both learning and entertainment aspects. Apart from that, verbal discussion with the respondents was simultaneously carried out to gather additional review towards the instrument. The respondents were asked to provide general comments on the instrument based on learning and entertainment aspects of comics.

Table $2 \mathrm{KMO}$ and Bartlett's test results

\begin{tabular}{lll}
\hline Kaiser-meyer-olkin measure of sampling adequacy. & & .873 \\
\hline Bartlett's Test of Sphericity & Approx. Chi-Square & 857.613 \\
& df & 190 \\
& Sig. & .000 \\
\hline
\end{tabular}

Table 3 Factor loadings results

\begin{tabular}{llll}
\hline Items & Loadings & Items & Loadings \\
\hline L1 & .660 & $\mathrm{E} 1$ & .673 \\
L2 & .770 & $\mathrm{E} 2$ & .562 \\
L3 & .694 & $\mathrm{E} 3$ & .652 \\
L4 & .692 & $\mathrm{E} 4$ & .708 \\
L5 & .578 & $\mathrm{E} 5$ & .736 \\
L6 & .708 & $\mathrm{E} 6$ & .715 \\
L7 & .694 & $\mathrm{E} 7$ & .756 \\
L8 & .611 & $\mathrm{E} 8$ & .649 \\
L9 & & \\
L10 & .545 & & \\
L11 & .534 & & \\
L12 & .632 & & \\
\hline
\end{tabular}

Table 4 Reliability test results

\begin{tabular}{lll}
\hline Dimensions & Cronbach's Alpha & N of Items \\
\hline Learning & .901 & 12 \\
\hline Entertainment & .879 & 8 \\
\hline
\end{tabular}

Table 5 Instrument for evaluating digital educational comic

\begin{tabular}{|c|c|c|}
\hline Aspects & & Description \\
\hline \multicolumn{3}{|c|}{ Learning } \\
\hline L1 & $\begin{array}{l}\text { Learning Goal } \\
\text { Alignment }\end{array}$ & $\begin{array}{l}\text { At what level the comic's ideas/questions/facts/pieces of information are relevant to the } \\
\text { topic? }\end{array}$ \\
\hline $\mathrm{L} 2$ & Agility & To what degree the text element in the comic is presented in short, concise segments? \\
\hline L3 & Typography & To what extent the font shapes, colours and size facilitate and stimulate reading? \\
\hline L4 & Consistency & $\begin{array}{l}\text { To what degree the comic makes use of certain pictorial consistency which adds } \\
\text { significantly to the learning process? }\end{array}$ \\
\hline L5 & Recipient & To what degree does the comic promote a positive attitude toward the topic? \\
\hline L6 & Reusability & $\begin{array}{l}\text { To what degree do the comic's native / digital / source files are file self-contained, } \\
\text { modular, traceable, modifiable, usable, standardized and properly grained, generic, and } \\
\text { platform independent? }\end{array}$ \\
\hline L7 & Accuracy & $\begin{array}{l}\text { At what level the ideas/questions/facts/pieces of information in the comic is accurate \& } \\
\text { free of errors? }\end{array}$ \\
\hline L8 & Reliability & At what level the quoted materials are visibly cited? \\
\hline L9 & Argumentation & $\begin{array}{l}\text { To what extent do the comic generate ideas/questions/facts/pieces of information about } \\
\text { the topic? }\end{array}$ \\
\hline
\end{tabular}


Syamsul Bahrin Zaibon et al.

\begin{tabular}{|c|c|c|}
\hline Aspects & & Description \\
\hline \multicolumn{3}{|c|}{ Learning } \\
\hline L10 & Thoroughness & $\begin{array}{l}\text { At what level the characters/personas interaction with the educational content are } \\
\text { meaningful and permit the reader to have a much greater understanding of the } \\
\text { concept/topic? }\end{array}$ \\
\hline L11 & $\begin{array}{l}\text { Emphasis of } \\
\text { Key Concepts }\end{array}$ & $\begin{array}{l}\text { Do the contents in the comic are easily balanced, distinguished or discernable from } \\
\text { fiction or fantasy? At what level the comic emphasis on key concepts? }\end{array}$ \\
\hline L12 & Prospective & $\begin{array}{l}\text { To what degree the story potentially open for sequel or continuation? Does it trigger } \\
\text { further questions related to the educational topic? }\end{array}$ \\
\hline \multicolumn{3}{|c|}{ Entertainment } \\
\hline E1 & Visual Appeal & $\begin{array}{l}\text { At what level the comic's illustrations/photos/graphics are appealing and aid the reader } \\
\text { in understanding the tone and mood of the story? }\end{array}$ \\
\hline E2 & Layout & $\begin{array}{l}\text { To what extent do the pictorials and words complement one another? At what level the } \\
\text { contrast and effects are used effectively to aid focus? }\end{array}$ \\
\hline E3 & Clear Instructions & $\begin{array}{l}\text { To what extent the story pace, shot, direction natural \& make sense to the reader? Do } \\
\text { the characters position are reasonably placed? }\end{array}$ \\
\hline E4 & Navigation & $\begin{array}{l}\text { To what degree the comic panels, speech balloons and captions placement ease and } \\
\text { flow of the story? Are the white space between the text, frames, and illustrations help } \\
\text { readers move through the comic, or are the pages too busy? }\end{array}$ \\
\hline E5 & Organization & $\begin{array}{l}\text { To what degree does the comic have a well-described setting with a clear beginning, } \\
\text { middle, and end? }\end{array}$ \\
\hline E6 & Plot & $\begin{array}{l}\text { To what extent the plot exhibit good development, imagination, and continuity? Does } \\
\text { the resolution bring the conflict to a satisfying end? }\end{array}$ \\
\hline E7 & Characters & $\begin{array}{l}\text { To what extent the characters are believable and well developed? Do the characters' } \\
\text { pose, gesture \& expression make sense in the story? }\end{array}$ \\
\hline E8 & Feedback & $\begin{array}{l}\text { At what level the plot and action necessarily give user adequate direction and } \\
\text { information for progressing to? }\end{array}$ \\
\hline
\end{tabular}

For instance, in the aspect of learning, the information on comic should be presented correctly and shortly, and concise segments. In addition, the character's interaction with the educational content should also meaningful as the dialog is aligned with the displayed information. Aside from that, the pictorials would be helpful to facilitate the reader's understanding towards the learning content; where in comic scene, the props (correct and incorrect signs) provide comparison and highlight important facts to the reader.

In the aspect of entertainment, the characters' pose, gesture, expression, and position is suggested to be reasonably placed. Other aspects, the speech balloons and caption placement in the comic also will ease the flow of the comic story and the pictorials complement with the plot. Finally, the comic should also provide enough context and action to keep the reader moving through the story. All these suggestions were taken into consideration for further improvement of the instrument.

\section{Conclusion}

This article sought to present the new instrument for evaluating digital educational comics. It has reported the development and validation of the instrument for its validity and reliability. The instrument focuses on the learning and entertainment aspects of digital educational comic. In specific, the instrument offers for measuring at what level the digital educational comic is able to educate and entertain the reader. Essentially, this study has provided adaptive criterion of educational and entertaining comic. Results from this study support the implementation of digital educational comic as a technology integrated classroom practice.

In this study, it was concluded that developing any kinds of instructional material is difficult to accomplish and needs meticulous considerations in the design and development process. It is because, both entertainment and learning are mainly relative to the age, gender, and socioeconomic background of learners [38]. Nevertheless, it seems highly recommended to utilize digital comic that may contribute to learning atmosphere inside or outside the classroom.

\section{Acknowledgment}

The authors would like to acknowledge the Ministry of Education for funding this project under the Fundamental Research Grant Scheme (SO Code: 13138) and Universiti Utara Malaysia for the research management and partly assisted under the Scholarship of Teaching and Learning Grants (SO Code: 13188). 
Conflicts of interest

The authors have no conflicts of interest to declare.

\section{References}

[1] Karczewski K. More than just iron man: a brief history of comic books and graphic novels. Crossroads. A Journal of English Studies. 2013; 3(3):47-51.

[2] Varnum R, Gibbons CT. The language of comics: word and image. Univ. Press of Mississippi; 2007.

[3] Eisner W. Comics \& sequential art. Tamarac, FL: Poorhouse Press; 1985.

[4] McCloud S. Understanding comics: the invisible art. Northampton, Mass. 1993.

[5] Cohn N. Comics, linguistics, and visual language: the past and future of a field. In linguistics and the study of comics 2012 (pp. 92-118). Palgrave Macmillan, London.

[6] Tatalovic M. Science comics as tools for science education and communication: a brief, exploratory study. Journal of Science Communication. 2009; 8(4):1-17.

[7] Cohn N. Un-defining "comics": separating the cultural from the structural in "comics". International Journal of Comic Art. 2005; 7(2):236-48.

[8] Palmer R. Combining the rhythms of comics and picturebooks: thoughts and experiments. Journal of Graphic Novels and Comics. 2014; 5(3):297-310.

[9] Goodbrey DM. From comic to hypercomic. In cultural excavation and formal expression in the graphic novel 2013 (pp. 291-302). Brill.

[10] Wang X. Designing interactive comics to affect time perception. ICCE 2014; (pp. 17-20).

[11] Steinke J. Science in cyberspace: science and engineering world wide web sites for girls. Public Understanding of Science. 2004; 13(1):7-30.

[12] Lai CH, Bjornerud PM, Akahori K, Hayashi S. The design and evaluation of language learning materials based on comic stories and comic strips. In international conference on computers in education 2002 (pp. 677-8). IEEE

[13] Rall H. Information graphics and comics. In interaktive infografiken 2013 (pp. 175-215). Springer Vieweg, Berlin, Heidelberg.

[14] Takacs ZK, Swart EK, Bus AG. Benefits and pitfalls of multimedia and interactive features in technologyenhanced storybooks: a meta-analysis. Review of Educational Research. 2015; 85(4):698-739.

[15] Meskin A. Defining comics? The Journal of Aesthetics and Art Criticism. 2007; 65(4):369-79.

[16] Robin B. The educational uses of digital storytelling. In society for information technology \& teacher education international conference 2006 (pp. 709-16). Association for the Advancement of Computing in Education (AACE).

[17] Smeda N, Dakich E, Sharda N. The effectiveness of digital storytelling in the classrooms: a comprehensive study. Smart Learning Environments. 2014; 1(6):1-21.

[18] Gakhar S, Thompson A. Digital storytelling: engaging, communicating, and collaborating. In society for information technology \& teacher education international conference 2007 (pp. 60712). Association for the Advancement of Computing in Education (AACE).

[19] Azman FN, Zaibon SB, Shiratuddin N. Pedagogical analysis of comic authoring systems for educational digital storytelling. Journal of Theoretical \& Applied Information Technology. 2016; 89(2):461-9.

[20] Jüngst H. Information comics-knowledge transfer in a popular format. Peter Lang . 2010.

[21] Cirigliano MM. Exploring the attitudes of students using an edutainment graphic novel as a supplement to learning in the classroom. Science Educator. 2012; 21(1):29-36

[22] Guimarães E. Comics as an educational tool. Intercom - brazilian society of interdisciplinary studies of communication. Annals in XXIV brazilian congress of communication - campo grande / MS 2001 (pp. 117).

[23] Gibson M. The state of the (sequential) art?: signs of changing perceptions of comics, manga and graphic novels in Britain. Going Graphic: Comics and Graphic Novels for Young People. 2010.

[24] Carter JB. Think piece: what i think i know about comics and ELA education. First Opinions, Second Reactions. 2013; 6(1):8-10.

[25] Zikmund WG, Carr JC, Babin B, Griffin M. Business research methods. Nelson Education; 2013.

[26] Pérez-Mateo M, Maina MF, Guitert M, Romero M. Learner generated content: quality criteria in online collaborative learning. European Journal of Open, Distance and E-Learning. 2011; 14(2):1-12.

[27] Van Sonderen E, Sanderman R, Coyne JC. Ineffectiveness of reverse wording of questionnaire items: let's learn from cows in the rain. PloS one. 2013; 8(7)

[28] Cooper S, Nesmith S, Schwarz G. Exploring graphic novels for elementary science and mathematics. School Library Research. 2011; 14:1-17.

[29] Griffith PE. Graphic novels in the secondary classroom and school libraries. Journal of Adolescent \& Adult Literacy. 2010; 54(3):181-9.

[30] Chawla S, Gupta N, Singla RK. LOQES: model for evaluation of learning object. International Journal of Advanced Computer Science and Applications. 2012; $3(7)$.

[31] Straub D, Boudreau MC, Gefen D. Validation guidelines for IS positivist research. Communications of the Association for Information Systems. 2004; 13(1):380-427.

[32] Wynd CA, Schaefer MA. The osteoporosis risk assessment tool: establishing content validity through a panel of experts. Applied Nursing Research. 2002; 15(3):184-8

[33] Oluwatayo JA. Validity and reliability issues in educational research. Journal of Educational and Social Research. 2012; 2(2):391-400.

[34] Hill R. What sample size is "enough" in internet survey research. Interpersonal Computing and Technology: An Electronic Journal for the 21st Century. 1998; 6(3-4):1-10. 
[35] Sekaran U, Bougie R. Research methods for business: a skill building approach. John Wiley \& Sons; 2016.

[36] Yu CH. Exploratory data analysis. Methods. 1977; 2:131-60.

[37] Var I. Multivariate data analysis. Vectors. 1998; 8(2):125-36.

[38] Azman FN, Zaibon SB, Shiratuddin N. Exploring digital comics as an edutainment tool: an overview. knowledge management international conference 2014(pp.589-94).

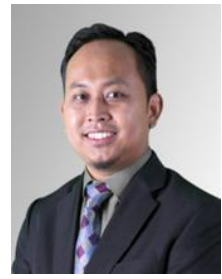

Syamsul Bahrin Zaibon is an Associate Professor at the School of Crea-tive Industry Management \& Performing Arts (SCIMPA) in Universiti Utara Malaysia (UUM). As a game based learning expert, he has published massive articles on mobile learning and mobile game development in prestigious academic journals and conferences. His previous inventions have accomplished gold, bronze and silver medals in PECIPTA2009, SIIF2009 and ITEX2014 Email: syamsulbahrin@uum.edu.my

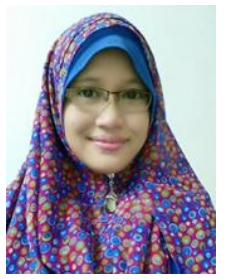

Farah Nadia Azman holds the position as a senior lecturer at the department of Interactive Media, FTMK, UTeM. She obtained her bachelor of Computer Science (Multimedia) on 2002 from UTM and gained her Masters Degree in IT at UKM on 2007. She has won awards through her academic innovations in MTE2011 and ITEX2012. Her $\mathrm{PhD}$ in Multimedia from the Universiti Utara Malaysia (UUM), Farah's interdisciplinary research between interactive technology and sequential art allows her to contribute to the adoption of comics within the Malaysian formal education system.

Email: farah@utem.edu.my

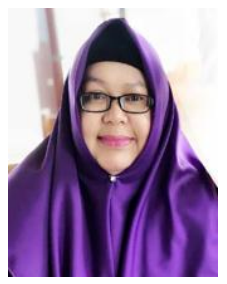

Norshuhada Shiratuddin is the Professor at the School of Multimedia technology \& Communication, Universiti Utara Malaysia (UUM). She has been successfully granted awards as Ahli Mangku Negara in 2007, Malaysian Association of Research Scientist, AIPPen 2012, APACMLEAP, K-Workers Development Initiative as well as nominated as a women icon in Majalah Wanita in 2012. She is a proud member of numerous professional international and national associations such as ACM, SIGSOFT, Adobe, IAENG, i3Net, IxDA, Malaysian Teachers Net, SKMM, MITS and many more.

Email:shuhada@uum.edu.my 